\title{
Comparison of intraoperative and post-operative effects of serratus anterior plane block performed with ultrasound and infiltration block in patients undergoing video-assisted thoracoscopic surgery
}

\author{
Video yardımlı torakoskopik cerrahi uygulanan hastalarda ultrasonografi eşliğinde yapılan \\ serratus anterior plane blok ile infiltrasyon blok uygulamasının intraoperatif \\ ve postoperatif etkinliklerinin karşılaştırılması
}

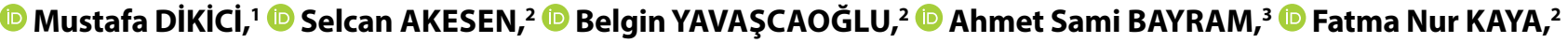 \\ (1) Alp GURBET ${ }^{2}$
}

\begin{abstract}
Summary
Objectives: We aimed to compare the intraoperative and post-operative analgesic activities of the preventive applied serratus anterior plane (SAP) block and infiltration block in patients undergoing video-assisted thoracoscopic surgery (VATS).

Methods: The study was carried out in 60 patients aged between 18 and 80 who were eligible for elective VATS, with the American Society of Anesthesiologists classification I-II, following ethical committee approval and written informed consent form. Patients were divided into two groups as SAP (group serratus anterior plane block [SAPB]) and group infiltration block after routine monitoring and general anesthesia induction by recording demographic data after randomization. Hemodynamic data of all patients were recorded before, after induction and within intraoperative $30 \mathrm{~min}$ period. Patient controlled analgesia (PCA) prepared with morphine was applied to all patients postoperatively. Intraoperative hemodynamic data and opioid consumption of patients, resting time, and coughing visual analog scale, time to first PCA dose, post-operative opioid consumption, rescue analgesic requirement, mobilization times, opioid side effects, and patient and surgical team's satisfaction were evaluated.

Results: Intraoperative hemodynamic data and opioid consumption were similar between the two groups. Post-operative pain scores ( 0 and 30 min, 1, 2, 4, 8, and $12 \mathrm{~h}$ ) were lower in the SAPB group $(p<0.005)$ and time to use the first PCA $(p=0.002)$ was longer in the SAPB group. Post-operative PCA and rescue analgesic requirement were lower in the SAPB group $(p=0.002, p=0.00)$. It was found that the first mobilization time was shorter in the SAPB group $(p=0.003)$, and opioid-related side effects were similar in both groups $(p=0.067)$. Patient and surgical team satisfaction was high in the SAPB group $(p=0.004, p=0.000)$.

Conclusion: As a result, more effective post-operative analgesia was provided with preventively SAPB, compared to infiltration block in patients undergoing VATS.
\end{abstract}

Keywords: Infiltration block; post-operative analgesia; serratus anterior plan block; video-assisted thoracoscopic surgery.

\section{Özet}

Amaç: Bu çalışmada video yardımlı torakoskopik cerrahi (VATS) uygulanacak hastalarda, preventif uygulanan serratus anterior plan (SAP) bloğu ve infiltrasyon bloğunun intraoperatif ve postoperatif analjezik etkinliklerini prospektif ve randomize kontrollü olarak karşılaştırmayı amaçladık.

Gereç ve Yöntem: Etik kurul onayı ve hastalardan alınan yazılı onam sonrası, elektif VATS uygulanacak, Amerikan Anestezistler Derneği (ASA) sınıflaması I-II olan, 18-80 yaş grubu 60 hasta çalışmaya dahil edildi. Hastalar randomizasyonu takiben demografik verileri kaydedilerek rutin monitorizasyon ve genel anestezi indüksiyonu sonrası, SAP (Grup SAPB) ve infiltrasyon blok (Grup iB) yapılan gruplar olarak ikiye ayrıldı. Tüm hastaların hemodinamik verileri indüksiyon öncesi, sonrası ve intraoperatif 30 dakikalık periyotlarda kaydedildi. Postoperatif bütün hastalara morfin ile hazırlanmış hasta kontrollü analjezi (HKA) uygulandı. Hastaların intraoperatif hemodinamik verileri ve opioid tüketimlerini, istirahat ve öksürmekle Vizüel Analog Skala (VAS) skorları, ilk HKA dozu gereksinim zamanı, postoperatif opioid tüketimleri, kurtarıcı analjezik gereksinimleri, mobilizasyon zamanları, opioid yan etkileri, hasta ve cerrahi ekibin memnuniyeti değerlendirildi. Bulgular: Intraoperatif hemodinamik veriler ve opioid tüketimleri her iki grupta benzer bulundu. SAPB grubunda postoperatif ağrı skorları (0. ve 30. dk, 1. 2. 4. 8. ve 12. sa) daha düşük ( $p<0.005)$ ve ilk HKA kullanım zamanının daha uzun olduğu saptandı $(p=0.002)$ Postoperatif HKA ve kurtarıcı analjezik gereksinimi SAPB grubunda daha düşük bulundu $(p=0.002, p=0.00)$. ilk mobilizasyon zamanının SAPB grubunda daha kısa olduğu ( $p=0.003$ ), opioide bağlı yan etkilerin her iki grupta benzer olduğu görüldü ( $p=0.067)$. Hasta ve cerrahi ekip memnuniyeti SAPB grubunda yüksekti $(p=0.004, p=0.000)$.

Sonuç: Sonuç olarak VATS uygulanan hastalarda preventif uygulanan SAP bloğu ile infiltrasyon bloğuna göre daha etkin postoperatif analjezi sağlanmıştır.

Anahtar sözcükler: Infiltrasyon bloğu; postoperatif analjezi; serratus anterior plan bloğu; video yardımlı torakoskopik cerrahi (VATS).

'Department of Anesthesiology and Reanimation, Bursa City Hospital, Bursa

2Department of Anesthesiology and Reanimation, Bursa Uludağ University Faculty of Medicine, Bursa

${ }^{3}$ Department of Thorax Surgery, Bursa Uludağ University Faculty of Medicine, Bursa, Turkey

Submitted (Başvuru tarihi) 10.11.2020 Accepted after revision (Düzeltme sonrası kabul tarihi) 13.05.2021 Available online date (Online yayımlanma tarihi) 04.11.2021 Correspondence: Dr. Selcan Akesen. Bursa Uludağ Üniversitesi Tıp Fakültesi, Anesteziyoloji ve Reanimasyon Anabilim Dalı, Bursa, Turkey.

Phone: +90 - 532 - 3971716 e-mail: selcanyerebakan@hotmail.com

(C) 2022 Turkish Society of Algology 


\section{Introduction}

Effective treatment of post-operative pain in patients scheduled for thoracic surgery accelerates recovery and decreases the rate of post-operative complications. In this way, early mobilization can be achieved and hospital stay can be shortened by preventing negative consequences of post-operative pain..$^{[1]}$

Compared to thoracotomy, video-assisted thoracoscopic surgery (VATS) has been reported to provide better pain control, lower costs, early mobilization in post-operative period, and improvement in pulmonary functions. ${ }^{[2]}$

The success of post-operative rehabilitation applications in patients undergoing thoracic surgery may be enhanced through minimally invasive surgical intervention (VATS) and multimodal pain control. At present, regional anesthesia techniques have come to the fore due to the potential side effects of opioids and nonsteroidal anti-inflammatory drugs (NSAIDs). ${ }^{[3]}$

Due to potential complications of thoracic epidural analgesia, paravertebral block, (PVB) and regional anesthesia techniques, there is a need for alternative regional methods.

In the present study, we aimed to make a comparison between the serratus anterior plane block performed with USG for preventive analgesia and infiltration block performed on the incision site in patients undergoing elective VATS procedure in terms of intraoperative and post-operative analgesic efficacy, patient-controlled analgesia (PCA) and morphine consumption, and patient and surgeon satisfaction.

\section{Material and Methods}

This study was conducted at the Anesthesiology and Reanimation and Thoracic Surgery Clinics of the Uludag University School of Medicine after obtaining written and verbal consents of the patients under the approval (2019-6/23) of Bursa Uludag University School of Medicine Ethics Committee. This prospective randomized study included 60 American Society of Anesthesiologists classification I-II patients who were aged 18-80 years old and scheduled for elective VATS between June 15, 2019, and February 15, 2020. Patients who had allergy to local anesthetics, known or suspected coagulopathy, infection at the injection site, history of thoracic surgery, a severe cardiovascular disease, hepatic or renal failure (glomerular filtration rate $<15 \mathrm{ml} / \mathrm{min} / 1.73 \mathrm{~m}^{2}$ ), severe neurological or psychiatric disorder, and chronic opioid use were not included in the study.

It was planned to exclude patients who were switched to thoracotomy, whose block application was unsuccessful (local anesthetic distribution was not appropriate; appropriate USG image could not be obtained), and who had problems with the PCA device. All patients were informed of the use of PCA device and of visual analog scale (VAS) to be applied in the post-operative period.

Using the closed envelope method, the patients were separated into two groups to undergo the selected block method for preventive analgesia.

Vascular access was established in the operating room using a $20 \mathrm{G}$ cannula. Premedication was achieved with $0.03 \mathrm{mg} / \mathrm{kg}$ intravenous (IV) midazolam (Zolamid ${ }^{\circledR}$, Defarma, Ankara, Turkey). Then, $3 \mathrm{ml} /$ $\mathrm{kg} / \mathrm{h}$ saline infusion was started. Routine electrocardiogram, non-invasive monitoring of blood pressure, and peripheral oxygen saturation $\left(\mathrm{SpO}_{2}\right)$ were performed.

After monitoring, anesthesia was induced with $1 \mathrm{mg} /$ $\mathrm{kg}$ lidocaine (Aritmal\% $2^{\circledR}$ Osel, Istanbul, Turkey), 2-3 $\mathrm{mg} / \mathrm{kg}$ propofol (Propofol 2\% Fresenius ${ }^{\oplus}$, Fresenius Kabi, Bad Hamburg, Germany), 1-2 mcg/kg fentanyl (Talinat ${ }^{\oplus}$, Vem, Istanbul, Turkey), and $0.6 \mathrm{mg} / \mathrm{kg}$ rocuronium (Esmeron ${ }^{\circledR}$, Merck Sharp and Dohme, New Jersey, USA) and the patients were intubated with either a left-sided or a right-sided double-lumen endobronchial tube (Sher-i-bronch ${ }^{\circledR}$ Teleflex, Pennsylvania, USA) according to the surgical site which is appropriate for the weight and height of the patients. Endotracheal tube placement was confirmed through listening to the respiratory sounds of both sides, end-tidal carbon dioxide monitoring and with fiber-optic bronchoscope, when necessary. The second venous cannula (18G or $16 \mathrm{G}$ ) was placed and, depending on the position, monitoring of invasive blood pressure was achieved by placing an arterial catheter (20G IV cannula) into the right or left radial artery. The patients were placed in the right or left lateral decubitus position according to the surgical side. 

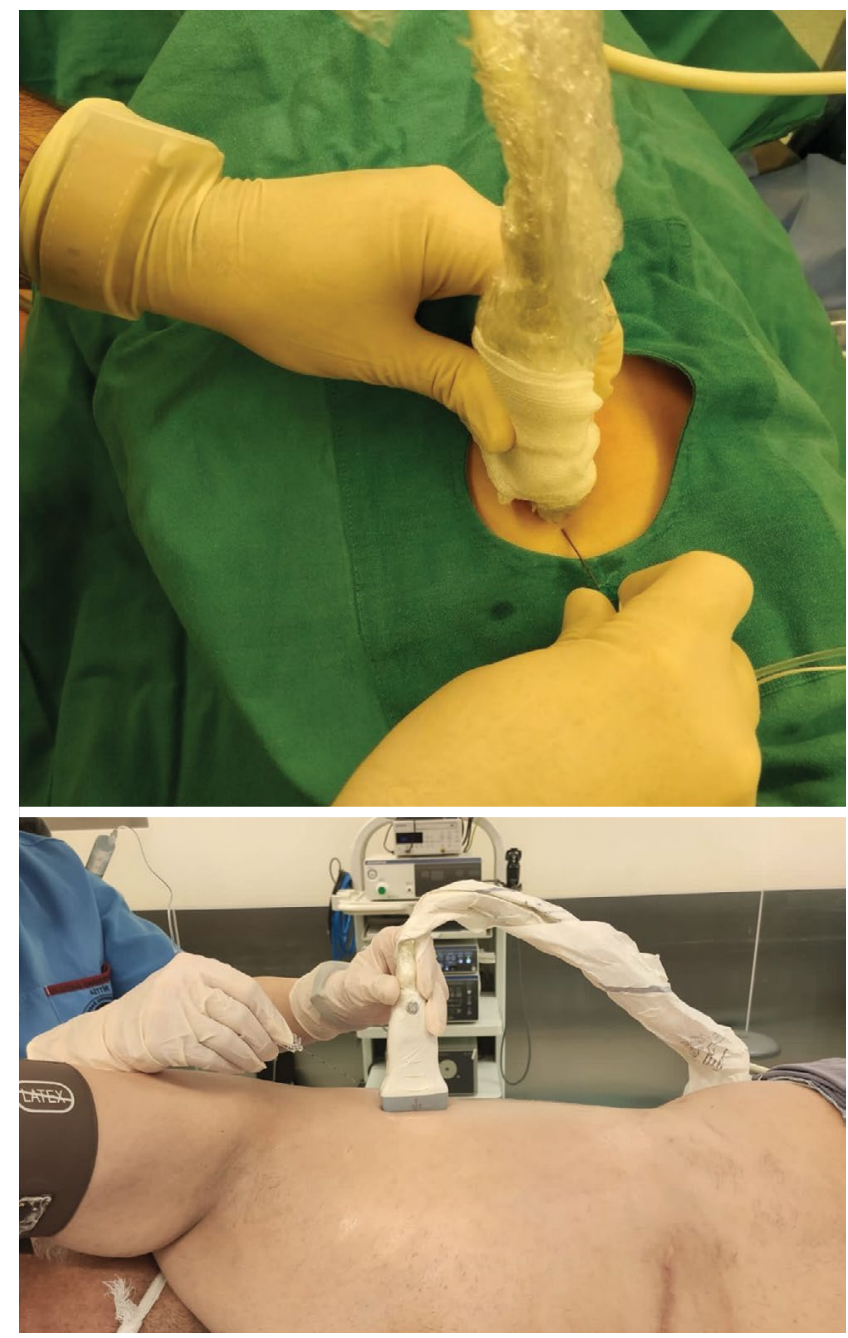

Figure 1. The position of the probe and needle insertion during block application.

Anesthesia was maintained with sevoflurane (Sevorane ${ }^{\circledR}$ Liquid 100\%, AbbVie, Queenborough Kent, UK) at a rate of $2 \mathrm{~L} / \mathrm{min}$ with a minimum alveolar concentration of 1 in a mixture of $50 \%$ air $+50 \%$ $\mathrm{O}_{2}$. It was planned to treat hypotension (mean arterial pressure [MAP] $<20 \%$ of the pre-operative value) with $5 \mathrm{mg}$ ephedrine and bradycardia $(\mathrm{HR}<40 / \mathrm{min})$ with $0.5 \mathrm{mg}$ atropine.

The blocks were performed with USG (Logiq $\mathrm{e}^{\circledR}$, GE, Boston, USA) by a single anesthesiologist or a surgeon, who were previously experienced in such blocks, before starting surgery.

Serratus anterior plane block (SAPB) group $(n=30)$ : While the patient was in the lateral decubitus position, a $10 \mathrm{MHz}$ linear USG probe (the linear probe was covered in a sterile manner after the area to be blocked was cleansed with antiseptic solution) was placed horizontally in the middle axillary line on the

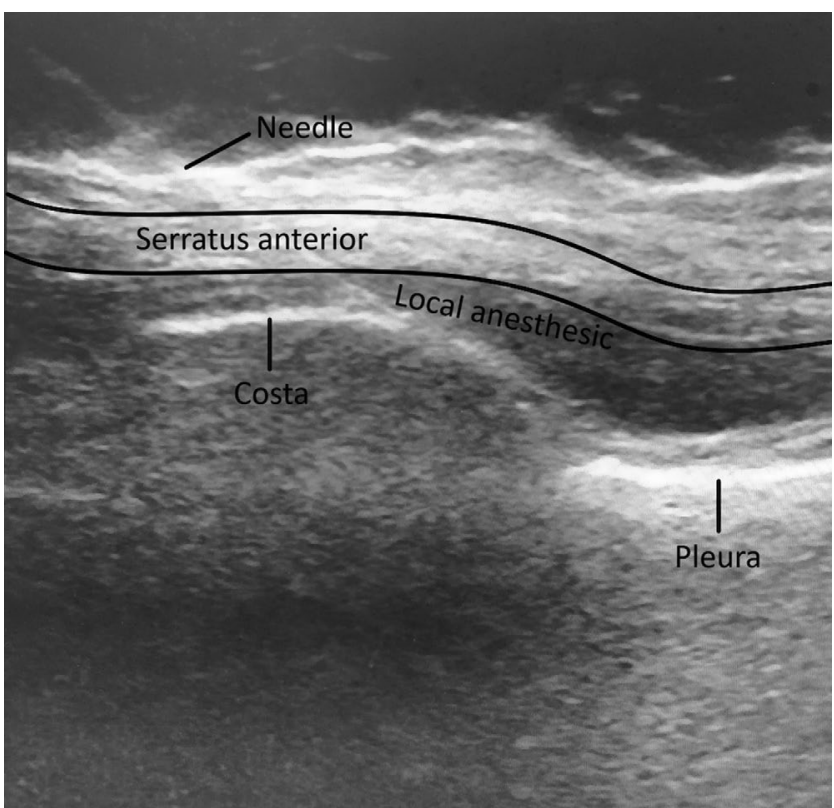

Figure 2. USG image of the serratus anterior plane block. LA: Local anesthetic.

side where the block would be performed. The serratus anterior, latissimus dorsi, and intercostal muscles were identified at the fourth and fifth intercostal levels. Block needle $\left(50 \mathrm{~mm} 22\right.$ gauge, Stimuplex ${ }^{\circledR}$ Ultra, B. Braun Melsungen AG, Germany) is placed under the serratus anterior muscle at the $1^{\text {st }}$ stage and then advanced between the serratus anterior and the latissimus dorsi in the $2^{\text {nd }}$ stage to be on the same plane with the USG probe (in-plane technique). The prepared bupivacaine $0.25 \%$ (Buvasin $0.5 \%{ }^{\oplus}$, Vem, Tekirdağ, Turkey) solution was administered on both sites at a dose of $0.25 \mathrm{~mL} / \mathrm{kg}$. It was observed with USG that the local anesthetic solution spreads both between the SAH and the ribs and between the SAH and the latissimus dorsi (Fig. 1, 2).

Infiltration block (IB) group $(n=30)$ : While the patients were in the lateral decubitus position, the trocar entry points suitable for the area to be operated and the periphery of ribs that make up the gap were controlled percutaneously through negative aspiration applied in a way that does not to cross the pleura. Bupivacaine $0.25 \%$ solution was injected in equal doses of $0.5 \mathrm{~mL} / \mathrm{kg}$ for each of the three trocar insertion sites, starting from the inner (pleura) to the outer (skin) and surrounding tissues.

Patients' MAP, heart rate (HR), and $\mathrm{SpO}_{2}$ values were recorded before anesthesia induction and at the $30^{\text {th }}, 60^{\text {th }}, 90^{\text {th }}$, and $120^{\text {th }}$ min after induction. In the event that MAP and/or HR increased by $20 \%$ or more 
at intervals between measurements at every $5 \mathrm{~min}$ in the intraoperative period, all such patients were given $0.5-1 \mathrm{mcg} / \mathrm{kg}$ IV fentanyl and administrations were recorded.

All patients were given metoclopramide (Primsel ${ }^{\circledR}$, Osel, Istanbul, Turkey) as anti-emetic prophylaxis for intraoperative nausea and vomiting. All patients were administered $1 \mathrm{~g}$ IV paracetamol (Partemol ${ }^{\circledR}$, And, Tekirdağ, Turkey) after induction and $20 \mathrm{mg}$ IV tenoxicam (Tilcotil ${ }^{\circledR}$ Deva, Tekirdağ, Turkey) 10 min before the end of the operation. At the end of the operation, the patients were given $2 \mathrm{mg} / \mathrm{kg}$ sugammadex (Bridion ${ }^{\circledR}$ Merck Sharp DORMA, Istanbul, Turkey) as muscle relaxant antagonist and transported to the recovery unit after extubation.

For post-operative pain control, a PCA device (CADD-Legacy ${ }^{\circledR}$ PCA, Smiths Medical, St. Paul, USA) was used. An IV serum concentration of $1 \mathrm{mg} / \mathrm{ml}$ was prepared with $90 \mathrm{ml}$ of saline and $100 \mathrm{mg}$ of morphine hydrochloride (Tramosel ${ }^{\circledR}$, Haver, Istanbul, Turkey). The PCA device was set to pump with a bolus dose of $2 \mathrm{ml}$, lockout time of $15 \mathrm{~min}$ without basal infusion and loading dose. The patients were transported to the thoracic surgery clinic after their vital signs became stable and the modified Aldrete score was $\geq 9$ (Annex-2). As of the recovery unit, patients were administered a bolus dose of morphine through the PCA device in case VAS $\geq 4$ when asked or on the complaint of the patient. It was planned to administer $50 \mathrm{mg}$ of IV dexketoprofen (Ketavel ${ }^{\circledR}$, Deva, Istanbul, Turkey) as the first rescue analgesic to patients, who had VAS $\geq 4$ despite PCA, and to give $50 \mathrm{mg}$ of tramadol (Tramosel ${ }^{\circledR}$, Haver, Istanbul, Turkey) as the second rescue analgesic when VAS $\geq 4$ persisted.

Patients' demographic data, intraoperative hemodynamic data and opioid requirement, VAS score at rest, and cough VAS (CVAS) scores measured in the recovery room $\left(1^{\text {st }} \mathrm{min}\right)$ and at the post-operative $30^{\text {th }}$ min and post-operative $1^{\text {st }}, 2^{\text {nd }}, 4^{\text {th }}, 8^{\text {th }}, 12^{\text {th }}$, and $24^{\text {th }} \mathrm{h}$; the $1^{\text {st }}$ time to use PCA, total morphine consumption, requirement for rescue analgesic, time of the first mobilization, opioid side effects (nauseavomiting, constipation, respiratory depression, and sedation), and the Likert scale for patient and surgeon satisfaction ( 1 - not at all satisfied and 5 - very satisfied) were recorded by an anesthesiologist who was blinded to the groups.

\section{Statistical Analysis}

We used the descriptive statistics of mean, standard deviation, median, minimum, maximum, frequency, and ratio. The Kolmogorov-Smirnov test was used to measure the distribution of the variables. The independent sample t-test and the Mann-Whitney U-test were employed in the analysis of quantitative independent data. The Chi-square test was used in the analysis of qualitative independent data, and when the Chi-square test conditions were not met, the Fisher's test was used. The SPSS 26.0 program was used for the analyses.

\section{Results}

As all operations were performed by the same single surgeon, the surgical approach was the same and three trocar entry openings were created for every patient. No blockade complications were observed in the groups. The distribution of the patients' demographic data is shown in Table 1.

The SAPB and IB groups were similar regarding the MAP measured before induction and at the $1^{\text {st }}, 60^{\text {th }}$, and $90^{\text {th }}$ min after induction $(p=0.297, p=0.053$, $p=0.089$, and $p=0.0237$ ). MAP value measured at the $30^{\text {th }}$ min after induction was significantly lower in the SAPB group as compared to the IB group $(p=0.031)$ (Table 2$)$.

The intraoperative need for fentanyl was similar in the two groups with $8.3 \pm 19.0 \mathrm{mcg}$ in the SAPB group and $15.0 \pm 23.3$ in the IB group $(p=0.226)$ (Table 3). In the SAPB group, time to need for PCA morphine was longer that the patients in the IB group $(p=0.002$ ) (Table 3 ).

In the SAPB group, the VAS at rest and CVAS scores measured at $0^{\text {th }} \min , 30^{\text {th }} \mathrm{min}, 60^{\text {th }} \mathrm{min}, 2^{\text {nd }} \mathrm{h}, 8^{\text {th }} \mathrm{h}$, and $12^{\text {th }} \mathrm{h}$ were significantly lower than in the IB group $(p<0.05)$. On the other hand, the VAS at rest and CVAS scores at the $24^{\text {th }}$ and $48^{\text {th }} \mathrm{h}$ were similar in the SAPB and IB groups (Table 4). Total IV morphine consumption was significantly higher in the SAPB group at the $0^{\text {th }}, 30^{\text {th }}$, and $60^{\text {th }}$ min and the $2^{\text {nd }}, 4^{\text {th }}$, $8^{\text {th }}, 12^{\text {th }}, 24^{\text {th }}$, and $48^{\text {th }} \mathrm{h}$ as compared to the IB group $(p<0.05)$ (Table 5). 
Table 1. Demographic data

\begin{tabular}{|c|c|c|c|c|c|c|c|c|c|}
\hline & \multicolumn{4}{|c|}{ Group SAPB } & \multicolumn{4}{|c|}{ Group IB } & \multirow[t]{2}{*}{$\mathbf{p}$} \\
\hline & Mean \pm SD & $\mathbf{n}$ & $\%$ & Median & Mean \pm SD & $\mathbf{n}$ & $\%$ & Median & \\
\hline Age (year) & $53.2 \pm 14.5$ & & & 55.0 & $52.4 \pm 14.3$ & & & 54.0 & $0.830^{t}$ \\
\hline \multicolumn{10}{|l|}{ Gender } \\
\hline Female & & 16 & 53.3 & & & 16 & 53.3 & & $1.000 \chi^{2}$ \\
\hline Male & & 14 & 46.7 & & & 4 & 46.7 & & \\
\hline $\mathrm{BMI}\left(\mathrm{kg} / \mathrm{m}^{2}\right)$ & $26.0 \pm 4.5$ & & & 26.5 & $28.0 \pm 5.9$ & & & 26.5 & $0.419^{m}$ \\
\hline \multicolumn{10}{|l|}{ ASA } \\
\hline 1 & & 8 & 26.7 & & & 10 & 33.3 & & $0.573 \chi^{2}$ \\
\hline 2 & & 22 & 73.3 & & & 20 & 66.7 & & \\
\hline \multicolumn{10}{|l|}{ Operation } \\
\hline Wedge resection & & 27 & 90.0 & & & 27 & 90.0 & & $1.000 \chi^{2}$ \\
\hline Pleural biopsy & & 3 & 10.0 & & & 3 & 10.0 & & \\
\hline
\end{tabular}

m: Mann-Whitney U-test; $\chi^{2}$ : Chi-square test; t: T-test; BMI: Body mass index; ASA: American Society of Anesthesiologists classification; SAPB: Serratus anterior plane block; IB: Infiltration block; SD: Standard deviation.

Table 2. Comparison of the MAP between groups

\begin{tabular}{|c|c|c|c|c|c|}
\hline \multirow[t]{2}{*}{ MAP (mmHg) } & \multicolumn{2}{|c|}{ Group SAPB } & \multicolumn{2}{|c|}{ Group IB } & \multirow[t]{2}{*}{$\mathbf{p}$} \\
\hline & Mean $\pm S D$ & Median & Mean $\pm S D$ & Median & \\
\hline Before induction & $104.0 \pm 2.7$ & 105.0 & $100.7 \pm 13.7$ & 103.5 & $0.27^{t}$ \\
\hline $1^{\text {st }}$ min after induction & $85.8 \pm 13.4$ & 86.0 & $92.1 \pm 11.5$ & 92.0 & $0.03^{t}$ \\
\hline $30^{\text {th }}$ min after induction & $84.0 \pm 12.7$ & 87.5 & $92.9 \pm 18.1$ & 94.0 & $0.031^{* t}$ \\
\hline $60^{\text {th }}$ min after induction & $82.3 \pm 17.8$ & 87.0 & $89.7 \pm 15.4$ & 87.5 & $0.089^{t}$ \\
\hline $90^{\text {th }}$ min after induction & $89.5 \pm 14.4$ & 85.0 & $91.6 \pm 11.9$ & 93.0 & $0.237^{t}$ \\
\hline
\end{tabular}

t: t-test; *: P<0.05 statistically significant; MAP: Mean arterial pressure; SAPB: Serratus anterior plane block; IB: Infiltration block; SD: Standard deviation.

It was observed that $63.3 \%(n=19)$ of the SAPB group and $16.7 \%(n=5)$ of the IB group did not require additional analgesic. On the other hand, 30\% $(n=9)$ of the SAPB group and $50 \%(n=15)$ of the control group required NSAIDs. In addition to NSAIDs, $6.7 \%$ of the SAPB group $(n=2)$ and $33.3 \%$ of the IB group $(n=10)$ needed opioid ( $p=0.001$ ) (Fig. 3a). The time to first mobilization was shorter in the SAPB group $(2.9 \pm 0.8$ h) than in the IB group ( $3.5 \pm 0.6 \mathrm{~h})(\mathrm{p}=0.003)$ (Fig. 3b).

Considering the side effects of opioids, nausea and vomiting were observed in $13.3 \%(n=4)$ of the patients in the SAPB group, but none of the patients had constipation, sedation, or respiratory depression. In the IB group, $16.7 \%(n=5)$ of the patients had nausea-vomiting, $6.7 \%(n=2)$ experienced sedation, $6.7 \%(n=2)$ had constipation, and $3.3 \%(n=1)$ had respiratory depression. The incidence of opioid side ef-

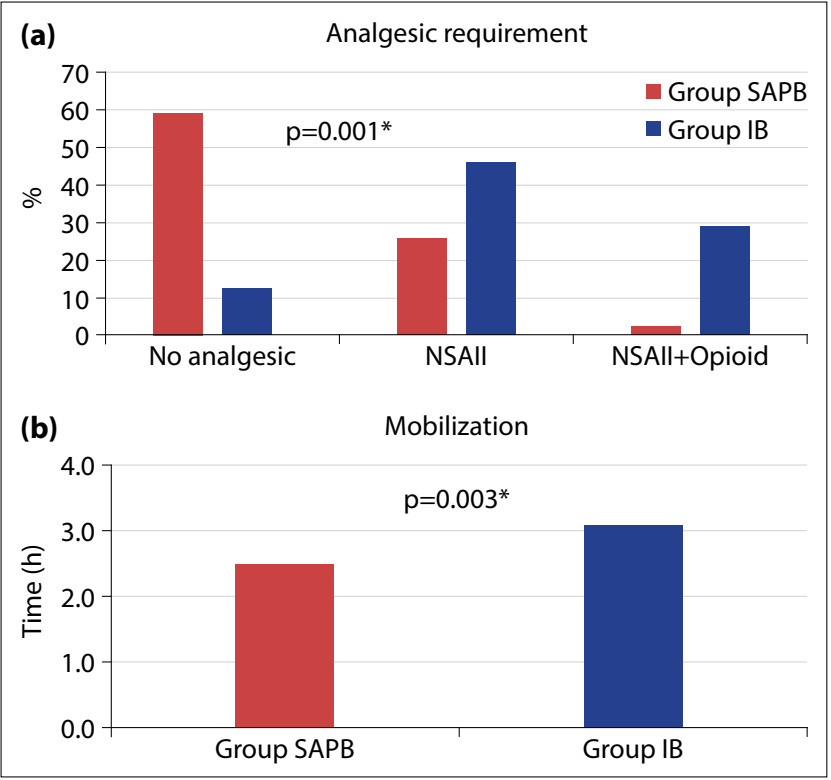

Figure 3. (a, b) Patients' additional analgesic requirements and mobilization times (\%, time).

*: $\mathrm{P}<0.05$ statistically significant. 
Table 3. Comparison of the groups regarding intraoperative fentanyl consumption and the mean time to require the first PCA

\begin{tabular}{|c|c|c|c|c|c|}
\hline & \multicolumn{2}{|c|}{ Group SAPB } & \multicolumn{2}{|c|}{ Group IB } & \multirow[t]{2}{*}{$\mathbf{p}$} \\
\hline & Mean \pm SD & Median & Mean \pm SD & Median & \\
\hline Intraoperative fentanyl consumption (mcg) & $8.3 \pm 19.0$ & 0.0 & $15.0 \pm 23.3$ & 0.0 & $0.226^{\mathrm{m}}$ \\
\hline \multicolumn{6}{|l|}{ Post-operative } \\
\hline The first PCA requirement (min) & $160.0 \pm 536.8$ & 0.0 & $7.0 \pm 24.5$ & 0.0 & $0.002^{* m}$ \\
\hline
\end{tabular}

m: Mann-Whitney U-test; $\chi^{2}$ : Chi-square test; ${ }^{*}$ : P<0.05 statistically significant; PCA: Patient-controlled analgesia; SAPB: Serratus anterior plane block; IB: Infiltration block; SD: Standard deviation.

Table 4. Comparison of the groups regarding VAS at rest and cough VAS

\begin{tabular}{|c|c|c|c|c|c|}
\hline & \multicolumn{2}{|c|}{ Group SAPB } & \multicolumn{2}{|c|}{ Group IB } & \multirow[t]{2}{*}{$\mathbf{p}$} \\
\hline & Mean \pm SD & Median & Mean \pm SD & Median & \\
\hline \multicolumn{6}{|c|}{ VAS score at rest $(0-10)$} \\
\hline $0^{\text {th }} \min$ & $2.0 \pm 1.4$ & 2.0 & $4.5 \pm 1.3$ & 5.0 & $0.000^{* m}$ \\
\hline $30^{\text {th }} \min$ & $1.9 \pm 1.3$ & 2.0 & $4.1 \pm 1.2$ & 4.0 & $0.000^{* m}$ \\
\hline $60^{\text {th }} \min$ & $1.9 \pm 1.2$ & 2.0 & $3.6 \pm 1.1$ & 4.0 & $0.000^{* m}$ \\
\hline $2^{\text {nd }} \mathrm{h}$ & $1.9 \pm 1.2$ & 2.0 & $3.5 \pm 1.1$ & 3.0 & $0.000^{*} \mathrm{~m}$ \\
\hline $4^{\text {th }} \mathrm{h}$ & $1.9 \pm 1.0$ & 2.0 & $3.0 \pm 0.9$ & 3.0 & $0.000^{* m}$ \\
\hline $8^{\text {th }} \mathrm{h}$ & $1.8 \pm 1.1$ & 2.0 & $2.8 \pm 0.9$ & 3.0 & $0.001^{* m}$ \\
\hline $12^{\text {th }} \mathrm{h}$ & $1.8 \pm 1.0$ & 2.0 & $2.2 \pm 0.7$ & 2.0 & $0.049^{* m}$ \\
\hline $24^{\text {th }} \mathrm{h}$ & $2.2 \pm 1.0$ & 2.0 & $2.3 \pm 0.5$ & 2.0 & $0.863^{\mathrm{m}}$ \\
\hline $48^{\text {th }} \mathrm{h}$ & $2.0 \pm 0.8$ & 2.0 & $1.8 \pm 0.5$ & 2.0 & $0.258^{\mathrm{m}}$ \\
\hline \multicolumn{6}{|c|}{ Cough VAS score (0-10) } \\
\hline $0^{\text {th }} \min$ & $3.7 \pm 1.7$ & 4.0 & $6.4 \pm 1.5$ & 7.0 & $0.000^{* m}$ \\
\hline $30^{\text {th }} \min$ & $3.7 \pm 1.6$ & 4.0 & $6.0 \pm 1.6$ & 6.0 & $0.000^{*} \mathrm{~m}$ \\
\hline $60^{\text {th }} \min$ & $3.3 \pm 1.6$ & 3.0 & $5.9 \pm 1.6$ & 6.0 & $0.000^{* m}$ \\
\hline $2^{\text {nd }} \mathrm{h}$ & $3.1 \pm 1.6$ & 3.5 & $5.5 \pm 1.1$ & 5.0 & $0.000^{* m}$ \\
\hline $4^{\text {th }} \mathrm{h}$ & $3.3 \pm 1.3$ & 4.0 & $5.1 \pm 1.3$ & 5.0 & $0.000^{* m}$ \\
\hline $8^{\text {th }} \mathrm{h}$ & $3.3 \pm 1.2$ & 3.0 & $5.0 \pm 1.0$ & 5.0 & $0.000^{*} \mathrm{~m}$ \\
\hline $12^{\text {th }} \mathrm{h}$ & $3.2 \pm 1.2$ & 3.0 & $4.3 \pm 0.9$ & 4.0 & $0.000^{*} \mathrm{~m}$ \\
\hline $24^{\text {th }} \mathrm{h}$ & $3.7 \pm 1.2$ & 3.5 & $4.2 \pm 0.8$ & 4.0 & $0.067^{m}$ \\
\hline $48^{\text {th }} \mathrm{h}$ & $3.4 \pm 1.3$ & 3.5 & $3.8 \pm 0.6$ & 4.0 & $0.198^{m}$ \\
\hline
\end{tabular}

m: Mann-Whitney U-test; *: P<0.05 statistically significant; VAS: Visual analog scale; SAPB: Serratus anterior plane block; IB: Infiltration block; SD: Standard deviation.

fects was lower in the SAPB group compared to the IB group, but no significant difference was found between the groups $(p=0.067)$. Patient and surgeon satisfaction scores were higher in the SAPB group compared to the IB group $(p=0.004, p=0.000)$ (Table 6).

\section{Discussion}

Besides increasing morbidity and mortality, inadequately treated pain may lead to several clinical and psychological changes including increased cost and decreased quality of life. ${ }^{[4]}$ While thoracic epidural anesthesia/analgesia and PVBs are specified as the gold standard for post-thoracotomy pain control, the optimal post-operative analgesia after VATS has not yet been defined. ${ }^{[5]}$

In this study, the intraoperative and post-operative effects of SAPB and infiltration block performed for 
Table 5. Comparison of SAPB and IB groups for total IV morphine consumption

\begin{tabular}{|c|c|c|c|c|c|}
\hline \multirow[t]{2}{*}{ Post-operative IV morphine (mg) } & \multicolumn{2}{|c|}{ Group SAPB } & \multicolumn{2}{|c|}{ Group IB } & \multirow[t]{2}{*}{$\mathbf{p}$} \\
\hline & Mean \pm SD & Median & Mean \pm SD & Median & \\
\hline $0^{\text {th }} \min$ & $1.2 \pm 1.2$ & 2.0 & $1.9 \pm 0.7$ & 2.0 & $0.009^{* m}$ \\
\hline $30^{\text {th }} \min$ & $2.4 \pm 2.1$ & 2.0 & $4.4 \pm 1.6$ & 4.0 & $0.000^{*} \mathrm{~m}$ \\
\hline $60^{\text {th }} \min$ & $3.7 \pm 2.4$ & 4.0 & $6.9 \pm 2.4$ & 8.0 & $0.000^{*} \mathrm{~m}$ \\
\hline $2^{\text {nd }} h$ & $4.8 \pm 3.1$ & 4.0 & $9.4 \pm 3.0$ & 10.0 & $0.000^{*} \mathrm{~m}$ \\
\hline $4^{\text {th }} \mathrm{h}$ & $6.2 \pm 3.7$ & 6.0 & $12.3 \pm 3.7$ & 12.0 & $0.000^{*} \mathrm{~m}$ \\
\hline $8^{\text {th }} \mathrm{h}$ & $7.4 \pm 4.3$ & 8.0 & $15.0 \pm 4.0$ & 16.0 & $0.000^{* m}$ \\
\hline $12^{\text {th }} \mathrm{h}$ & $8.7 \pm 4.8$ & 8.0 & $17.7 \pm 5.0$ & 19.0 & $0.000^{*} \mathrm{~m}$ \\
\hline $24^{\text {th }} \mathrm{h}$ & $11.0 \pm 5.9$ & 11.0 & $20.9 \pm 5.6$ & 22.0 & $0.000^{*} \mathrm{~m}$ \\
\hline $48^{\text {th }} \mathrm{h}$ & $11.9 \pm 5.4$ & 12.0 & $22.6 \pm 6.5$ & 24.0 & $0.000^{*} \mathrm{~m}$ \\
\hline
\end{tabular}

m: Mann-Whitney U-test; *: P<0.05 statistically significant; SAPB: Serratus anterior plane block; IB: Infiltration block; SD: Standard deviation.

Table 6. Comparison of the groups regarding patients and surgeon satisfaction scores

\begin{tabular}{lcccccc} 
& \multicolumn{2}{c}{ Group SAPB } & & \multicolumn{2}{c}{ Group IB } & \multirow{p}{*}{} \\
\cline { 2 - 3 } & Mean \pm SD & Median & & Mean \pm SD & Median & \\
\hline Patient satisfaction 1-5 & $4.1 \pm 1.0$ & 4.0 & & $3.3 \pm 1.0$ & 3.0 & $0.004^{*} \mathrm{~m}$ \\
Surgeon satisfaction 1-5 & $4.2 \pm 0.9$ & 4.5 & & $3.3 \pm 0.9$ & 3.0 & $0.000^{*} \mathrm{~m}$ \\
\hline
\end{tabular}

*: P<0.05 statistically significant; SAPB: Serratus anterior plane block; IB: Infiltration block; SD: Standard deviation.

preventive analgesia in patients undergoing VATS under general anesthesia were compared in a prospective, randomized controlled manner.

Similar to the literature, ${ }^{[6,7]}$ we did not find any significant difference between the two groups in intraoperative $\mathrm{SpO}_{2}$ and $\mathrm{HR}$ values. Although MAP values were generally similar between the groups, the MAP measured at 30 min after anesthesia induction was found to be significantly lower in the SAPB group. This result was attributed to the efficacy of SAPB.

Kim et al ${ }^{[8]}$ divided 90 patients scheduled for VATS, into two groups and applied USG-guided SAPB either with $0.4 \mathrm{~mL} / \mathrm{kg}$ of ropivacaine $0.375 \%$ (SPB group) or saline solution (control group) that there was no significant difference between the groups regarding intraoperative opioid consumption. It was revealed in the prospective, randomized study by Lee et al. ${ }^{[7]}$ investigating intraoperative opioid consumption in patients who underwent thoracoscopic surgery that intraoperative opioid consumption was lower in the USG-guided SAPB group as compared to the control group, and it was concluded that SAPB is a safe and ef- fective regional anesthesia technique for VATS operations. There is no study investigating intraoperative opioid consumption in the literature on infiltration block in patients who underwent thoracic surgery, and we found that intraoperative opioid consumption was similar between the two groups in our study.

In their randomized controlled study comparing SAPB and local anesthetic infiltration, Chen et al. ${ }^{[9]}$ assessed VAS at rest and CVAS scores in the post-operative period and found that both VAS at rest and CVAS scores were lower in the SAPB group compared to the infiltration group. Fiorelli et al. ${ }^{[10]}$ performed infiltration block on 18 patients who underwent bilateral thoracoscopic sympathectomy by injecting lidocaine on the one side and saline on the other side of the same patient, and stated that the VAS scores were significantly lower at the post-operative $4^{\text {th }}$ and $24^{\text {th }} \mathrm{h}$ on the side where lidocaine was administered, and that at the $128^{\text {th }} h$, the scores were still lower but not at significant level.

In this study, VAS and CVAS scores were found to be significantly lower in the SAPB group than in the in- 
filtration group during $12 \mathrm{~h}$ after surgery. However, VAS and CVAS scores at the $24^{\text {th }}$ and $48^{\text {th }} \mathrm{h}$ were similar in the SAPB and IB groups. It was thought that the fact that there was no difference in VAS and CVAS scores at the $24^{\text {th }}$ and $48^{\text {th }} \mathrm{h}$ might be related with the half-life of the local anesthetic agent.

In this study, time to use PCA was significantly longer in the SAPB group compared to the infiltration group. Nevertheless, the total amount of morphine consumed was found to be higher in the infiltration group compared to the SAPB group.

Park et al. ${ }^{[11]}$ reported in their prospective, randomized study in which they divided patients undergoing thoracoscopic surgery into two groups as with and without SAPB that the total fentanyl requirement was higher in the control group in the postoperative period except for the $6^{\text {th }}$ and $24^{\text {th }} \mathrm{h}$. It was reported in a prospective, randomized, blind, single-center study in which Ökmen and Ökmen ${ }^{[12]} \mathrm{di-}$ vided 40 patients into two groups to receive SAPB with $20 \mathrm{ml}$ of $0.25 \%$ bupivacaine plus IV tramadol through PCA and to receive only IV tramadol through PCA that PCA tramadol consumption at $h$ 6,12 , and 24 was significantly lower the group in which SAPB was performed compared to the other group. Ökmen and Ökmen suggested that SAPB can be an effective treatment option for analgesia after thoracoscopic surgery.

Chen et al. ${ }^{[9]}$ divided 40 patients undergoing thoracoscopic surgery into two groups and applied infiltration block by injecting $0.4 \mathrm{ml} / \mathrm{kg}$ of $0.25 \%$ ropivacaine in one group while applying SAPB by injecting $15 \mathrm{ml}$ of $0.25 \%$ ropivacaine through two trocar entries to the other group. Chen et al. ${ }^{[9]}$ reported that opioid consumption was significantly lower in the SAPB group till the post-operative $8^{\text {th }}$ $h$, but there was no difference between the groups from $8^{\text {th }}$ to $16^{\text {th }}$ and $16^{\text {th }}$ to $24^{\text {th }} \mathrm{h}$.

Ökmen and Ökmen ${ }^{[12]}$ compared the SAPB with a control group in the prospective study in which they divided 40 patients who underwent VATS into two groups. They administered tramadol by IV PCA in both groups in the post-operative period, and they stated that none of the patients in the SAP group needed additional rescue analgesic, where- as three patients in the other group required additional IV paracetamol, but there was no significant difference between the groups.

Semyonov et al. ${ }^{[13]}$ randomized 104 patients who underwent thoracic surgery into two groups in their prospective, randomized, double-blind and single-center study. While IV opioids and NSAIDs were given to the first group, the other group underwent SAPB in addition to these drugs. They found that the need for rescue analgesic (tramadol) in the post-operative period was less in the SAPB group. The authors reported that SAPB is an effective treatment option for analgesia after thoracic surgery, since it is easy to apply and has a low potential for side effects compared to existing methods. In the present study, we obtained data consistent with the literature and found out that both NSAID and tramadol requirements were lower in the SAPB group compared to the other group.

It is known that mobilization in the early period after thoracic surgery reduces pulmonary complications such as atelectasis and pneumonia, and positively contributes to the healing process. ${ }^{[14]}$ In our study, the time to post-operative mobilization was shorter in the SAPB group than in the infiltration group.

In general, it is seen in the literature that patients who underwent thoracic surgery experience severe pain in the postoperative period and frequently need analgesics during this process, and these analgesics have serious effects on morbidity, especially when the side effects of opioids are considered.

In their retrospective study, Wang et al. ${ }^{[15]}$ divided their 123 patients into three groups as the SAPB, $P V B$, and control groups and reported that the rates of post-operative nausea and vomiting were lower in the groups who were applied blocks as compared to the control group, without the difference being significant. Furthermore, the rates of sedation and urinary retention were found to be similar in the three groups.

Chen et al. ${ }^{[9]}$ compared SAPB and infiltration analgesia in their prospective study and stated that the rate of post-operative nausea-vomiting was 
considerably lower in the SAPB group than in the infiltration group, but the difference was not statistically significant.

Our data are parallel to the information in literature. We monitored patients for potential nauseavomiting, sedation, and respiratory depression in the post-operative period. Although the incidence of side effects was lower in the SAPB group, there was no significant difference between the groups. We think that this result may be due to the PCA device decreasing side effects by limiting the morphine level administered in a certain time or due to the sample size.

Park et al. ${ }^{[11]}$ compared 89 patients in two groups, USG-guided SAPB group and the control group and indicated higher patient satisfaction in the SAPB group. In this study, both patient satisfaction and surgeon satisfaction were higher in the group applied with SAPB as compared to the IB group.

The first limitation of our study is the absence of a control group. Although the distribution of local anesthetics was clearly seen with USG during SAPB and IB application, the distribution of dermatoma and the efficacy of the block could not be evaluated as the procedures were applied after general anesthesia. Blood levels of the local anesthetics were not measured and that the number of times when patients needed PCA could not be recorded since the PCA device was not able to respond to the patient's analgesic requirement during the lockout time.

\section{Conclusion}

Consequently, SAPB is superior to infiltration block in post-operative pain management after thoracoscopic surgery. Moreover, SAPB can be applied as a part of multimodal analgesia as it is a simple and effective block; it reduces the need for postoperative opioids and analgesics, and allows early mobilization. The fact that the patients and the surgical team were highly satisfied about the use of preventive SAPB has encouraged us to work with different protocols on these issues.

\section{Conflict-of-interest issues regarding the authorship or article: None declared.}

Peer-rewiew: Externally peer-reviewed.

\section{References}

1. Yegin A, Arslan A, Karslı B, Trakya A. The comparison of intrapleural, intercostal and preemptive analgesia in postthoracotomy pain relief. Türk Klin 2003;23(2):141-5.

2. Nagahiro I, Andou A, Aoe M, Sano Y, Date H, Shimizu N. Pulmonary function, postoperative pain, and serum cytokine level after lobectomy: A comparison of VATS and conventional procedure. Ann Thorac Surg 2001;72(2):362-5. CrossRef]

3. Slinger PD, Campos JH. Anesthesia for thoracic surgery. In: Miller RD, editor. Miller's Anesthesia. $8^{\text {th }}$ ed. Philadelphia, PA: Elsevier, Saunders; 2015. p. 1942-2006.

4. Apfelbaum JL, Chen C, Mehta SS, Gan TJ. Postoperative pain experience: results from a national survey suggest postoperative pain continues to be undermanaged. Anesth Analg 2003;97(2):534-40 [CrossRef]

5. Elmore B, Nguyen V, Blank R, Yount K, Lau C. Pain management following thoracic surgery. Thorac Surg Clin 2015;25(4):393-409. [CrossRef]

6. Viti A, Bertoglio $P$, Zamperini $M$, Tubaro A, Menesterina $\mathrm{N}$, Bonadiman $\mathrm{S}$, et al. Serratus plane block for video-assisted thoracoscopic surgery major lung resection: a randomized controlled trial. Interact Cardiovasc Thorac Surg 2020;30(3):366-72. [CrossRef]

7. Lee J, Kim S. The effects of ultrasound-guided serratus plane block, in combination with general anesthesia, on intraoperative opioid consumption, emergence time, and hemodynamic stability during video-assisted thoracoscopic lobectomy: a randomized prospective study. Medicine (Baltimore) 2019;98(18):e15385. [CrossRef]

8. Kim DH, Oh YJ, Lee JG, Ha D, Chang YJ, Kwak HJ. Efficacy of ultrasound-guided serratus plane block on postoperative quality of recovery and analgesia after video-assisted thoracic surgery: a randomized, triple-blind, placebo-controlled study. Anesth Analg 2018;126(4):1353-61 [CrossRef]

9. Chen G, Li Y, Zhang Y, Fang X. Effects of serratus anterior plane block for postoperative analgesia after thoracoscopic surgery compared with local anesthetic infiltration: A randomized clinical trial. J Pain Res 2019;12:2411-7. [CrossRef]

10. Fiorelli A, Vicidomini G, Laperuta P, Busiello L, Perrone A, Napolitano F, et al. Pre-emptive local analgesia in videoassisted thoracic surgery sympathectomy. Eur J Cardiothorac Surg 2010;37(3):588-93 [CrossRef]

11. Park MH, Kim JA, Ahn HJ, Yang MK, Son HJ, Seong BG. A randomised trial of serratus anterior plane block for analgesia after thoracoscopic surgery. Anesthesia 2108;73(10):12604. CrossRef]

12. Ökmen K, Metin Ökmen B. Evaluation of the effect of serratus anterior plane block for pain treatment after video-assisted thoracoscopic surgery. Anaesth Crit Care Pain Med 2018;37(4):349-53.[CrossRef]

13. Semyonov $M$, Fedorina $E$, Grinshpun J, Dubilet $M$, Refaely $\mathrm{Y}$, Ruderman $\mathrm{L}$, et al. Ultrasound-guided serratus anterior plane block for analgesia after thoracic surgery. J Pain Res 2019;12:953-60,[CrossRef]

14. Muehling BM, Halter GL, Schelzig $H$, Meierheinrich R, Steffen $\mathrm{P}$, Plassmann LS, et al. Reduction of postoperative pul- 
monary complications after lung surgery using a fast track clinical pathway. Eur J Cardiothorac Surg 2008;34(1):17480. [CrossRef]

15. Wang L, Wang Y, Zhang X, Zhu X, Wang G. Serratus anterior plane block or thoracic paravertebral block for postoperative pain treatment after uniportal video-assisted thoracoscopic surgery: A retrospective propensity-matched study. J Pain Res 2019;12:2231-8. [CrossRef] 